\title{
Fragmentation of Protonated Thioether Conjugates of Acrolein Using Low Collision Energies
}

\author{
Christa H. Oberth and A. Daniel Jones \\ Facility for Advanced Instrumentation, University of California, Davis, California, USA
}

\begin{abstract}
The protonated mercapturic acid conjugate of acrolein, $S$-(3-oxopropyl)- $N$-acetyl-L-cysteine (I), undergoes facile retro-Michael loss of acrolein in the gas phase. To determine whether extensive loss of acrolein would impede structural characterization of acrolein-peptide adducts, fragmentation reactions of a series of conjugates, formed by 1,4-Michael addition of acrolein to peptides and cysteine derivatives, were investigated at collision cell potentials up to $-50 \mathrm{~V}$ using a triple quadrupole mass spectrometer. Differences in fragmentation dynamics suggest protonation at the sulfur of the $N$-acetylcysteine conjugate I facilitates retro-Michael elimination of acrolein with a low activation energy relative to other fragmentations. Analogous fragmentation was eliminated after borohydride reduction of the aldehyde to an alcohol. Retro-Michael fragmentation was not significant for acrolein conjugates of glutathione derivatives, suggesting that proton sequestration occurs in peptides with multiple amide linkages even when the peptide does not contain a basic amino group. An unexpected outcome of these experiments was the observation of a facile gas-phase cleavage of peptides on the $N$-terminal side of $S$-(3-oxopropyl)cysteine residues. Such fragmentation behavior may prove useful for locating cysteine residues in peptides. (J Am Soc Mass Spectrom 1997, 8, 727-736) (c) 1997 American Society for Mass Spectrometry
\end{abstract}

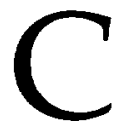

ovalent modification of proteins and DNA by reactive electrophiles such as xenobiotic metabolites can lead to cancer or cell death [1]. Protein sulfhydryl groups are especially vulnerable to electrophilic attack and form thioether conjugates whose presence indicates mechanisms of metabolic activation or detoxification. Knowledge of protein targets and sites of covalent attachment can be used to identify reactive metabolites, and these modified proteins can serve as biomarkers of exposure to xenobiotics in clinical and epidemiological studies [1-8]. One important class of xenobiotic-protein adducts forms via 1,4-Michael addition of $\alpha, \beta$-unsaturated carbonyls to nucleophilic amino acid residues. Many $\alpha, \beta$-unsaturated carbonyls including acrylic monomers, combustion by-products or metabolites such as acrolein [1], and endogenous compounds such as 4-hydroxynonenal react with protein nucleophilic side chains via Michael addition [9-11].

Mass spectrometry has emerged as a powerful analytical tool for the characterization of post-translationally modified peptides and proteins because this approach can identify the modifying group and sites of modification [12]. Earlier studies demonstrated the utility of fast atom bombardment mass spectrometry (FAB/MS) for identification of specific thioether conju-

Address reprint requests to Dr. A. Daniel Jones, Facility for Advanced Instrumentation, Unuversity of California, Davis, CA 95616. E-mail: adjones@ucdavis.edu gates from biological samples [3, 4, 13-17]. Using $\mathrm{FAB}$ or newer ionization techniques coupled with tandem mass spectrometry (MS/MS), researchers determined structures of thioether conjugates extracted from biological matrices [3-8, 13-22]. In these MS/MS experiments, structural information was obtained from collision induced dissociation (CID). In fact, Murphy et al. [20] concluded that fragmentation patterns of thioether conjugates have much in common, but that universal recognition of class characteristic ions has been uncertain.

More detailed information regarding activation energies for specific fragmentation reactions can be obtained by generating energy resolved product ion spectra. Energy resolved product ion spectra are acquired by making incremental changes in collision cell potential and determining the dependence of product ion abundances on the translational energy of precursor ions [23, 24]. At the lowest collision energies, only fragmentation reactions with the lowest activation energies are accessible. Incremental increases in collision energy provide access to reaction pathways leading to more and different product ions [23-28]. Normalized product ion abundances can be plotted to show their dependence upon collision cell potential. These graphs are termed energy resolved dissociation curves, and they assist efforts to optimize CID experiments aimed at structure determination or specific detection. Subtle differences in fragmentation dynamics are easily stud- 


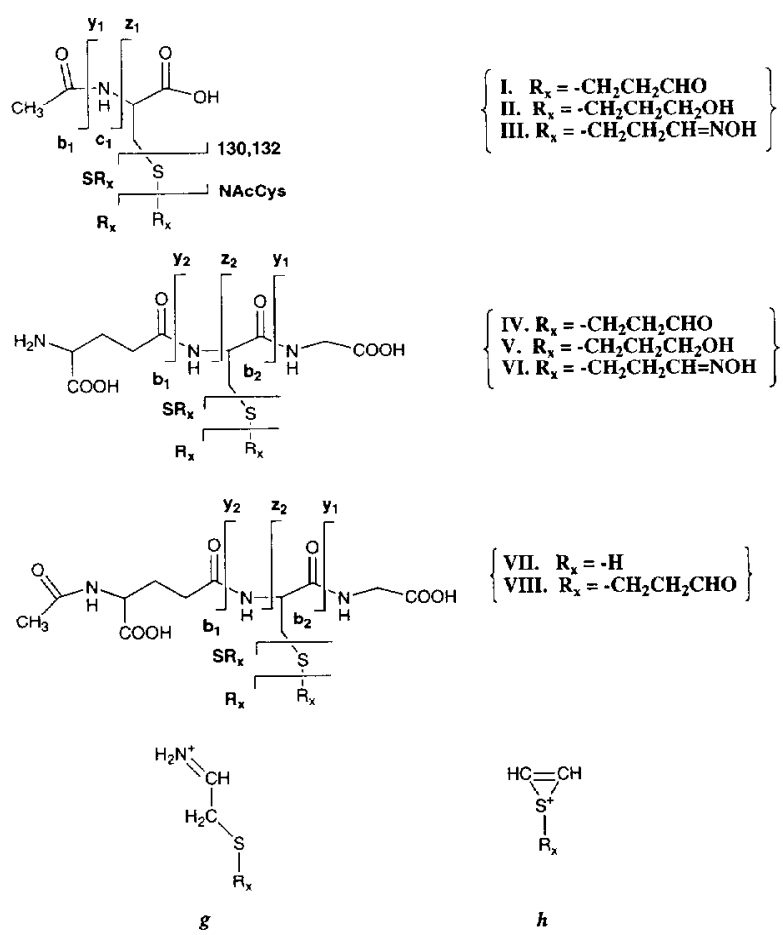

Figure 1. Structures of thioether conjugates used in this study.

ied by using tandem quadrupole instruments where ion-molecule collisions are low energy processes [23-25, 27-33]. In such experiments, most fragmentation is charge directed as fragmentation barriers are lowered by a nearby positive charge.

Electrospray and $F A B$ ionization of peptides yield protonated molecules in which the proton can be coordinated by hydrogen bonding along several sites of the peptide backbone [29-35]. Because thioether conjugates of $N$-acetylcysteine have fewer sites for proton coordination, their fragmentation behavior can be different than larger peptide thioether conjugates.

The principal aim of this study has been to determine relationships between structural features and fragmentation dynamics in protonated acrolein thioether conjugates by using low energy CID tandem mass spectrometry experiments. This has been accomplished by generating energy resolved product ion spectra [23-28] for a series of structurally related peptides that vary in size and in the number of basic functional groups. Acrolein thioether conjugates were chosen as model compounds for Michael-thioether conjugates. Acrolein is an important industrial chemical $[1,36]$, a metabolite of the cancer chemotherapeutic agent cyclophosphamide, [36-38] and an unwanted side-product of combustion and cigarette smoke [38, 39]. Compounds for this study are acrolein conjugates of $N$-acetyl-L-cysteine, glutathione, and $N$-acetylglutathione. Derivatives of the aldehyde groups were prepared from these conjugates to assess whether common derivatization of the aldehyde group would alter fragmentation behavior. Structures of thioether conjugates used in this study are displayed in Figure 1.

\section{Experimental}

\section{Materials}

Caution: Acrolein is a potent and toxic lachrymator and should be hundled in a fume hood to minimize exposure. Sodium borohydride is a toxic flammable solid and should be handled carefully.

$\mathrm{N}$-Acetylcysteine, glutathione, and oxidized glutathione (GSSG) were obtained from Sigma (St. Louis, $\mathrm{MO})$. Acrolein, sodium borohydride $\left(\mathrm{NaBH}_{4}\right)$, hydroxylamine hydrochloride, trifluoroacetic acid (TFA), and Sephadex QAE-A-50, were obtained from Aldrich (Milwaukee, WI). Acetic anhydride, acetonitrile, and dithiothreitol were from Fisher (Pittsburgh, PA). Bond-Elut $\mathrm{CBA}$ solid phase extraction cartridges were from Analytichem (Varian, Harbor City, CA). All water used in the following procedures was obtained from a Barnstead/Thermolyne (Dubuque, IA) Nanopure water filtration system.

\section{Synthesis}

Syntheses of conjugates were conducted by adding acrolein to solutions of various thiols, flushing the headspace of the reaction vials to remove oxygen, and keeping reaction vials wrapped in aluminum foil to prevent photochemical degradation. Reaction progress was monitored by using free zone capillary electrophoresis (CE) with spectrophotometric detection at 214 $\mathrm{nm}$. When reactions were complete, products were placed under a stream of nitrogen to remove unreacted acrolein and acetonitrile, and the remaining moisture was removed by lyophilization. Synthetic thioether conjugates in this study were stored under nitrogen at $-30^{\circ} \mathrm{C}$.

$N$-Acetylcysteine Conjugates. S-(3-Oxopropyl)- $N$-acetylL-cysteine (Compound I) was synthesized by dissolving $20 \mathrm{mg}$ of $N$-acetylcysteine $(0.12 \mathrm{mmoles})$ in one $\mathrm{mL}$ of a 1:1 (v:v) acetonitrile:water solution. $20 \mu \mathrm{L}$ of acrolein $(0.30 \mathrm{mmol})$ was added by micropipette. ${ }^{1} \mathrm{H}$ NMR results are in agreement with spectra published earlier [37, 40] (in $\mathrm{d}_{3}$-acetonitrile): $1.93 \mathrm{ppm}$ (s, acetyl $\mathrm{Me}, 3 \mathrm{H}), 2.67\left(\mathrm{tt},-\mathrm{S}-\mathrm{CH}_{2}-\mathrm{CH}_{2}-\mathrm{CH}=\mathrm{O}, \mathrm{C}-2,2 \mathrm{H}\right), 2.77$ (dt, $-\mathrm{S}-\mathrm{CH}_{2}-\mathrm{CH}_{2}-\mathrm{CH}=\mathrm{O}, \mathrm{C}-1,2 \mathrm{H}$ ), 2.95 (dq, Cys- $\beta, 2$ $\mathrm{H}), 4.55(\mathrm{dt}$, Cys- $\alpha, 1 \mathrm{H}), 6.89$ (d, amide, $1 \mathrm{H}), 9.65(\mathrm{t}$, $\left.-\mathrm{S}-\mathrm{CH}_{2}-\mathrm{CH}_{2}-\mathrm{C} \underline{\mathrm{H}}=\mathrm{O}, 1 \mathrm{H}\right)$. ESI MS results: $m / z 220$ $[\mathrm{M}+\mathrm{H}]^{+}$.

Conversion of $5.2 \mathrm{mg}$ of I $(0.024 \mathrm{mmol})$ to $\mathrm{S}-(3-$ hydroxypropyl)- $N$-acetyl-L-cysteine (Compound II) was accomplished by dissolving I in $2 \mathrm{~mL} 95 \%$ ethanol/ water followed by addition of $1 \mathrm{mg} \mathrm{NaBH}$. The mixture was sonicated for 20 minutes in an ultrasound bath. An additional $1 \mathrm{mg}$ of $\mathrm{NaBH}_{4}$ was added and the mixture sonicated for an additional $10 \mathrm{~min}$. Unreacted $\mathrm{NaBH}_{4}$ was quenched by dropwise addition of $0.1 \mathrm{~N}$ $\mathrm{HCl}$ (until gas evolution stopped, $\mathrm{pH} 4.0$ ). Purification of II was performed by using a Sephadex QAE-A-50 
anion exchange column. The column was pretreated with successive washes with absolute ethanol and water. The quenched reaction product was loaded on the anion exchange column and the column was washed with water to elute residual sodium ion. Compound II was eluted from the column with $0.1 \%$ trifluoroacetic acid in water. This eluted fraction was then lyophilized. The ${ }^{1} \mathrm{H}$ NMR spectrum agreed with a published spectrum [37] and showed no detectable starting material. NMR spectrum (in $\mathrm{D}_{2} \mathrm{O}$ ): 1.91 ppm (s, acetyl $\mathrm{Me}, 3 \mathrm{H}$ ), $1.82\left(\mathrm{~m},-\mathrm{S}-\mathrm{CH}_{2}-\mathrm{CH}_{2}-\mathrm{CH}_{2}-\mathrm{OH}, \mathrm{C}-2,2 \mathrm{H}\right), 2.65(\mathrm{t}$, $-\mathrm{S}-\mathrm{CH}_{2}-\mathrm{CH}_{2}-\mathrm{OH}, \overline{\mathrm{C}-1}, 2 \mathrm{H}$ ), 29.95 (d of q, Cys- $\beta, 2 \mathrm{H}$ ), 3.67 ( $t,-\mathrm{S}-\mathrm{CH}_{2}-\mathrm{CH}_{2}-\mathrm{CH}_{2}-\mathrm{OH}, \mathrm{C}-3,2 \mathrm{H}$ ), 4.36 (d of d, Cys $-\alpha, 1$ H). ESI MS results: $m / z 222[\mathrm{M}+\mathrm{H}]^{+}$.

Tosynthesize $S$-(3-N-hydroxyiminopropyl)- $N$-acetylL-cysteine (Compound III, a mixture of two geometric isomers), $4.9 \mathrm{mg}$ of Compound I (0.022 mmoles) was dissolved in $1.0 \mathrm{~mL}$ of $0.2 \mathrm{M}$ ammonium carbonate $(\mathrm{pH}$ $8) .15 \mathrm{mg}$ of solid hydroxylamine hydrochloride $(0.22$ mmoles) was added to the above solution and mixcd by using a vortex mixer. ${ }^{1} \mathrm{H}$ NMR (in $\mathrm{D}_{2} \mathrm{O}$ ): $2.05 \mathrm{ppm}(\mathrm{s}$, acetyl Me, $3 \mathrm{H}), 2.51$ (q, $-\mathrm{S}-\mathrm{CH}_{2}-\mathrm{CH}_{2}-\mathrm{CH}=\mathrm{NOH}$ (trans), $\mathrm{C}-2,2 \mathrm{H}), 2.68\left(\mathrm{t},-\mathrm{S}-\mathrm{CH}_{2}-\mathrm{CH}_{2}-\mathrm{CH}=\mathrm{NOH}\right.$ (cis), $\mathrm{C}-2,2 \mathrm{H}), 2.77\left(\mathrm{~m},-\mathrm{S}-\mathrm{CH}_{2}-\mathrm{CH}_{2}-\mathrm{CH}=\mathrm{NOH}, \mathrm{C}-1\right.$, $2 \mathrm{H}), 3.0(\mathrm{~m}$, Cys- $\beta, 2 \mathrm{H}), 4.4$ (t of d, Cys- $\alpha, 1 \mathrm{H}), 6.91(\mathrm{t}$, $\left.-\mathrm{S}-\mathrm{CH}_{2}-\mathrm{CH}_{2}-\underline{\mathrm{CH}}=\mathrm{NOH}(\mathrm{cis}), \mathrm{C}-3,1 \mathrm{H}\right), 7.51(\mathrm{t}$, $-\mathrm{S}-\mathrm{CH}_{2}-\mathrm{CH}_{2}-\mathrm{C} \overline{\mathrm{H}}=\mathrm{NOH}$ (trans), $\left.\mathrm{C}-3,1 \mathrm{H}\right)$. ESI MS results: $m / z 235[\mathrm{M}+\mathrm{H}]^{+}$.

Glutathione Conjugates. To synthesize S-(3-oxopropyl)glutathione (Compound IV), $10 \mu \mathrm{L}$ of acrolein in acetonitrile solution $(0.69 \mathrm{M})$ was added to $1 \mathrm{~mL}$ aqueous solution containing $20 \mathrm{mg}(0.065 \mathrm{mmol})$ of glutathione. Three additional $10 \mu \mathrm{L}$ aliquots of acrolein/acetonitrile were added at successive one hour intervals. When the reaction was complete, the product was placed under a stream of nitrogen to remove unreacted acrolein and acetonitrile, then frozen and lyophilized. ${ }^{1} \mathrm{H}$ NMR spectra agree with published results [37] (in $\mathrm{D}_{2} \mathrm{O}$ ): $2.14 \mathrm{ppm}$ (q, Glu- $\beta, 2 \mathrm{H}), 2.52$ (dt, Glu- $\gamma, 2 \mathrm{H}), 2.63\left(\mathrm{t},-\mathrm{S}-\mathrm{CH}_{2}-\mathrm{CH}\right.$ $\left.{ }_{2}-\mathrm{CH}=\mathrm{O}, \mathrm{C}-2,2 \mathrm{H}\right), 2.83$ [t (obscured by overlapping $\mathrm{m}$ at $\left.2.88 \mathrm{~J},-\mathrm{S}-\mathrm{CH}_{2}-\mathrm{CH}_{2}-\mathrm{CH}=\mathrm{O}, \mathrm{C}-1,2 \mathrm{H}\right), 2.88(\mathrm{~m}$, Cys- $\beta, 2 \mathrm{H}), 3.79(\mathrm{t}, \mathrm{Glu}-\alpha, 1 \mathrm{H}), 3.94(\mathrm{~s}, \mathrm{Gly}-\alpha, 1 \mathrm{H}), 4.58$ (m, Cys- $\alpha, 1 \mathrm{H}), 9.65\left(\mathrm{t},-\mathrm{S}-\mathrm{CH}_{2}-\mathrm{CH}_{2}-\mathrm{CH}=\mathrm{O}, 1 \mathrm{H}\right)$. ESI MS results: $m / z 364[\mathrm{M}+\overline{\mathrm{H}}]^{+}$.

Reduction of IV to S-(3-hydroxypropyl)glutathione (Compound $\mathrm{V}$ ) was accomplished by addition of $1 \mathrm{mg}$ $\mathrm{NaBH}_{4}$ to a solution of $6.0 \mathrm{mg}$ of IV $(0.017 \mathrm{mmol})$ in 1 $\mathrm{mL}$ of $90 \%$ ethanol in water $(\mathrm{v} / \mathrm{v})$. The mixture was sonicated for 30 minutes in an ultrasound bath to ensure mixing. An additional $1 \mathrm{mg}$ of $\mathrm{NaBH}_{4}$ was added and sonicated for another $10 \mathrm{~min}$. Unreacted $\mathrm{NaBH}_{4}$ was quenched as described above. The $\mathrm{pH}$ of the mixture was raised to $\mathrm{pH} 9$ with $1 \mathrm{M}$ ammonium carbonate and $1 \mathrm{M}$ sodium hydroxide to ensure retention of $\mathrm{V}$ on the anion-exchange column for purification as described for II. ${ }^{1} \mathrm{H}$ NMR (in $\left.\mathrm{D}_{2} \mathrm{O}\right): 1.79(\mathrm{~m}$, $\left.-\mathrm{S}-\mathrm{CH}_{2}-\mathrm{CH}_{2}-\mathrm{CH}_{2}-\mathrm{OH}, \mathrm{C}-2,2 \mathrm{H}\right), 2.17$ (q, Glu- $\beta, 2 \mathrm{H}$ ), 2.54 (d, Glu- $\gamma, 2 \mathrm{H}$ ), $2.63\left(\mathrm{t},-\mathrm{S}-\mathrm{CH}_{2}-\mathrm{CH}_{2}-\mathrm{CH}_{2}-\mathrm{OH}, \mathrm{C}-1\right.$,
$2 \mathrm{H}), 2.86(\mathrm{~m}, \mathrm{Cys}-\beta, 2 \mathrm{H}), 3.64,\left(\mathrm{t},-\mathrm{S}-\mathrm{CH}_{2}-\mathrm{CH}_{2}-\mathrm{CH}_{2}-\right.$ $\mathrm{OH}, \mathrm{C}-3,2 \mathrm{H}), 3.90$ (t, Glu- $\alpha, 1 \mathrm{H}), 3.98$ (s, Gly- $\alpha, 2 \mathrm{H}$ ), 4.56 ( $m$, Cys- $\alpha, 1 \mathrm{H})$. ESI MS: $m / z 366[\mathrm{M}+\mathrm{H}]^{+}$.

To synthesize the oxime $S-(3-N$-hydroxyiminopropyl)glutathione (Compound VI), $6.0 \mathrm{mg}$ of IV $(0.017$ mmol) was derivatized with $16.2 \mathrm{mg}(0.23 \mathrm{mmol})$ hydroxylamine hydrochloride in $0.5 \mathrm{M}$ ammonium acetate pH 7.0. ${ }^{1} \mathrm{H}$ NMR (in $\mathrm{D}_{2} \mathrm{O}$ ): $2.13 \mathrm{ppm}(\mathrm{q}, \mathrm{Glu}-\boldsymbol{\beta}, 2 \mathrm{H}$ ), 2.49 (d, Glu- $\gamma, 2 \mathrm{H}), 2.64\left(\mathrm{q},-\mathrm{S}-\mathrm{CH}_{2}-\mathrm{CH}_{2}-\mathrm{CH}=\mathrm{NOH}\right.$ (trans), $\mathrm{C}-2,2 \mathrm{H}), 2.76\left(\mathrm{~m},-\mathrm{S}-\mathrm{CH}_{2}-\mathrm{CH}_{2}-\mathrm{CH}=\mathrm{NOH}\right.$, $\mathrm{C}-1,2 \mathrm{H}$ ), $2.85\left(\mathrm{q},-\mathrm{S}-\mathrm{CH}_{2}-\mathrm{CH}_{2}-\mathrm{CH}=\mathrm{NOH}\right.$ (cis), $\mathrm{C}-2,2$ $\mathrm{H}), 3.05$ ( $\mathrm{m}$, Cys- $\beta, 2 \mathrm{H}$ ), 3.74 [t (obscured by Gly- $\alpha$ ), Glu- $\alpha, 1 \mathrm{H}$ ], 3.76 (s, Gly- $\alpha, 2 \mathrm{H}$ ), 4.59 (t, Cys- $\alpha, 1 \mathrm{H}$ ), 6.85 (t, $-\mathrm{S}-\mathrm{CH}_{2}-\mathrm{CH}_{2}-\mathrm{CH}=\mathrm{NOH}$ (cis), C-3, $1 \mathrm{H}$ ), 7.50 (t, $-\mathrm{S}-\mathrm{CH}_{2}-\mathrm{CH}_{2}-\mathrm{CH}=\mathrm{NOH}$ (trans) $\mathrm{C}-3,1 \mathrm{H}$ ). ESI MS: $m / z 379\left[\mathrm{M}+\mathrm{H}^{+}\right.$.

$N$-Acetylglutathione Conjugates. N-Acetylglutathione (Compound VII) was synthesized by dissolving $16 \mathrm{mg}(0.026$ mmoles) oxidized glutathione (GSSG) in $200 \mu \mathrm{L}$ of acetonitrile:water $(50 / 50 \mathrm{v} / \mathrm{v})$ followed by addition of $200 \mu \mathrm{L}(2.1$ mmoles) acetic anhydride. The mixture was held at $70^{\circ} \mathrm{C}$ for 18 hours. After cooling, volatile byproducts were removed under a stream of nitrogen. Reduction of the disulfide bond of acetylated GSSG was accomplished by dissolving the glassy product in $1 \mathrm{~mL}$ of water followed by addition of 7.8 $\mathrm{mg}$ (0.05 mmoles) dithiothreitol. The reduction was allowed to proceed at $25^{\circ} \mathrm{C}$ for four hours. Dithiothreitol was removed using a Sephadex QAE-A-50 anion exchange column pretreated with successive washes with $100 \%$ ethanol and water. The reaction products were loaded on the column, washed with $7 \mathrm{~mL}$ of water followed by elution of the product with $7 \mathrm{~mL}$ of acetonitrile containing $0.1 \%$ trifluoroacetic acid. The eluted product was lyophilized. Confirmation of VII was performed by ESI MS: $m / z 350[\mathrm{M}+\mathrm{H}]^{+}$. To synthesize S-(3-oxopropyl)- $N$-acetylglutathione (Compound VIII) VII was dissolved in $1 \mathrm{~mL}$ of water and $0.5 \mathrm{~mL}$ of this solution was mixed with $4.6 \mathrm{~mL}(0.098 \mathrm{mmol})$ of acrolein. The reaction mixture was left at $25^{\circ} \mathrm{C}$ for $4 \mathrm{~h}$ and lyophilized. ESI mass spectra confirmed formation of VIII: $m / z 406[\mathrm{M}+\mathrm{H}]^{+}$.

\section{Instrumentation}

${ }^{1} \mathrm{H}$ NMR spectra were recorded on a General Electric S-300 (Fremont, CA) spectrometer (7 Tesla) operating at room temperature. ${ }^{1} \mathrm{H}$ chemical shifts are expressed as ppm downfield from tetramethylsilane. All mass spectra were acquired using a VG Quattro-BQ triple quadrupole mass spectrometer (VG Biotech, Altrincham, UK) connected to a microflow pump (model $\mu$ LC-500, Isco Inc., Lincoln, NE). The solvent system (1:1 acetonitrile:water $\mathrm{v}: \mathrm{v}$ ) was delivered to the ionization source at a flow rate of $5 \mu \mathrm{L} / \mathrm{min}$. Loop injections of 10 $\mu \mathrm{L}$ were made by using analytes dissolved in a 1:1 acetonitrile:water solution (approximate final concentration, $30 \mathrm{pmol} / \mu \mathrm{L}$ ). The source temperature was held at $65^{\circ} \mathrm{C}$, and the capillary voltage was set at $+3.5 \mathrm{kV}$. 
Table 1. Partial list of product ions observed at collision cell potential of $-50 \mathrm{~V}$

\begin{tabular}{|c|c|c|c|c|c|c|c|c|c|c|c|c|}
\hline \multirow[b]{2}{*}{ Precursor ion } & \multicolumn{12}{|c|}{ Product ion $\mathrm{m} / \mathrm{z}(\% \text { relative abundance })^{\mathrm{a}}$} \\
\hline & $b_{1}$ & $V_{1}$ & $\mathrm{z}_{2}$ & $\mathbf{b}_{2}$ & $V_{2}$ & Acetyl & $\begin{array}{c}\text { Loss of } \\
\mathrm{C}_{2} \mathrm{H}_{2} \mathrm{O} \\
\text { (ketene) }\end{array}$ & $\begin{array}{c}\text { Loss of } \\
\mathrm{C}_{2} \mathrm{H}_{5} \mathrm{NO} \\
\text { (acetamide) }\end{array}$ & $\mathbf{g}$ & $\mathrm{h}$ & $\mathrm{SR}_{x}$ & $R_{x}$ \\
\hline $\mathrm{N}$-AcCysteine & $N A^{e}$ & NA & NA & NA & NA & $43(100)$ & $122(95)$ & $105(55)$ & $76\{90\}$ & $59(67)$ & NA & NA \\
\hline I & NA & NA & NA & NA & NA & $43(17)$ & $178(33)$ & $161(64)$ & $132(27)$ & $115(22)$ & $89(100)$ & $57(7)$ \\
\hline II & NA & NA & NA & NA & NA & $43(19)$ & $180(43)$ & $163(100)$ & $134(18)$ & $117(54)$ & $91(78)$ & $59(12)$ \\
\hline III & NA & NA & NA & NA & NA & $43(15)$ & $194(7)$ & $176(10)$ & $147(10)$ & $130(48)^{c}$ & $105(55)$ & $72(93)$ \\
\hline Glutathione & $130(30)$ & $76(100)^{\mathrm{b}}$ & $162(27)$ & $233(7)$ & $179(30)$ & NA & NA & NA & $76(100)$ & $59(6)$ & NA & NA \\
\hline IV & $130(60)$ & $76(23)$ & $N D^{e}$ & $289(6)$ & ND & NA & NA & NA & $132(65)$ & $115(75)$ & $89(40)$ & $57(16)$ \\
\hline v & $130(60)$ & $76(15)$ & $220(55)$ & $291(6)$ & $237(10)$ & NA & NA & NA & $134(30)$ & $117(95)$ & $91(18)$ & $59(7)$ \\
\hline VI & $130(61)^{\mathrm{d}}$ & 76 (52) & $233(17)$ & $304(12)$ & ND & NA & NA & NA & $147(13)$ & $130(61)$ & $104(100)$ & $72(40)$ \\
\hline VII & $172(35)$ & $76(32)^{b}$ & ND & $275(10)$ & $179(21)$ & $43(2)$ & $307(10)$ & 291 (3) & $76(32)$ & ND & NA & NA \\
\hline VIII & $172(27)$ & $76(7)$ & ND & $331(11)$ & ND & ND & ND & ND & $132(40)$ & $115(5)$ & $89(12)$ & ND \\
\hline
\end{tabular}

${ }^{a} A$ bundance relative to base peak (excluding precursor) $=100$.

bProduct ion $\mathrm{m} / \mathrm{z} 76$ from GSH and VII parent may consist of mixtures of isobars: $v_{1}$ and $g$.

cProduct ion $\mathrm{m} / \mathrm{z} 130$ from 111 may also include isobar due to loss of $\mathrm{SR}_{x}$ to form pratonated dehydroalanine.

dProduct ion $\mathrm{m} / \mathrm{z} 130$ from VI may consist of an isobaric pair: $b_{1}$ and $h$.

${ }^{e}$ Abbreviations: N-AcCysteine: $N$-acetyl-L-cysteine; NA, not applicable; ND, not detected $(<2 \%$ base peak abundance).

The resolution of the first quadrupole was adjusted to give a peak width at half-height of about $0.75 \mathrm{Da}$. For tandem mass spectrometry experiments, argon was introduced into the collision cell at a measured pressure $1.0 \times 10^{-3}$ mbar. The resolution of the second quadrupole was adjusted to give a peak width at half-height of 1.5 Da. This setting allowed sufficient ion beam transmission to ensure signal-to-noise ratio adequate for spectrum interpretation. Ion kinetic energies through the first quadrupole were set to $2 \mathrm{eV}$.

Individual scans were averaged using Masslynx ${ }^{\mathrm{TM}}$ multichannel acquisition (MCA) mode. Product ion spectra were obtained at $20 \mathrm{~s} / \mathrm{scan}$ to ensure reliable quantitative measurements of weak signals where ion statistics limited precision of peak height measurements. The collision cell potentials (negative) used to generate energy resolved product ion spectra were 0,5 , $10,20,35$, and $50 \mathrm{~V}$.

\section{Energy Resolved Dissociation Curves}

Energy resolved dissociation curves were produced by plotting normalized product ion intensities against collision cell potential. Normalized relative intensities of specific product ions were calculated by using the formula:

$$
\frac{i_{j}}{\sum_{j+k}^{i} \cdots}
$$

where $i_{j}$ is the intensity of a selected product ion and $\sum i_{j+k} \cdots$ is the summation of all product ion intensities with relative intensity of $2 \%$ or higher.

\section{Nomenclature}

Peptide fragmentation nomenclature used throughout this report is based on the Roepstorff and Fohlman [41] nomenclature for peptide cleavages as modified by Biemann [42]. The single letter nomenclature used for proposed internal fragments has been described by Haroldsen et al. [13] and Ballard et al. [17]. Nomenclature for product ions arising from cleavage at the sulfur are based on conventions proposed by Deterding et al. [15], where $R_{x}$ denotes the xenobiotic moiety.

\section{Results and Discussion}

To facilitate comparisons of fragments derived from the compounds used in this study, a partial list of product ions generated by using a collision cell potential of -50 $\mathrm{V}$ is provided in Table 1.

\section{N-Acetylcysteine Conjugates}

Preliminary high energy CID experiments $\left(E_{\text {lab }}=8000\right.$ $\mathrm{eV}$, not shown) on the acrolein conjugate of $\mathrm{N}$-acetylcysteine revealed the predominance of retro-Michael loss of acrolein from protonated I. In the current study, energy resolved product ion spectra of $N$-acetylcysteine were obtained (not shown) to establish the relative ease of fragmentation of the bonds in $\mathrm{N}$-acetylcysteine without influence of a modifying group. Spectra of product ions derived from protonated $\mathrm{N}$-acetylcysteine were obtained under the same collisional activation conditions used throughout these experiments. The most prevalent fragmentation route for $N$-acetylcysteine was formation of protonated cysteine $(m / z 122)$ via loss of ketene $\left(\mathrm{C}_{2} \mathrm{H}_{2} \mathrm{O}\right)$. Another product generated at all collision potentials was observed at $\mathrm{m} / z 76$, which is attributed to successive losses of ketene and $\mathrm{CO}_{2}$ producing fragment $g$ (see Figure 1 for description). The acetyl ion $(m / z$ 43) was observed at higher collision potentials.

Representative product spectra from CID of protonated I are displayed in Figure 2. The dominant frag- 
o volts
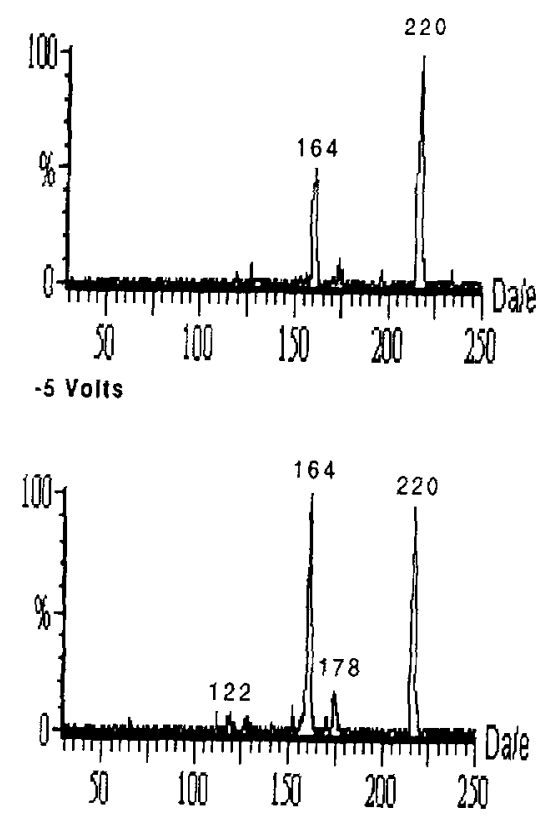

-10 Volts

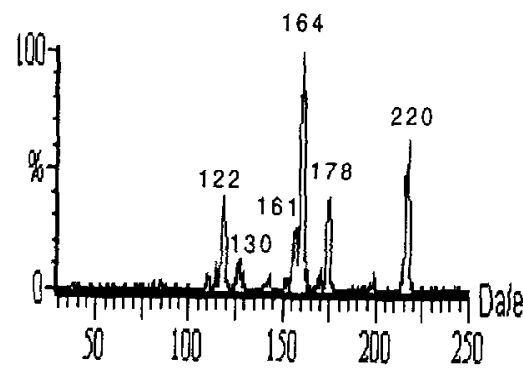

-20 Volts
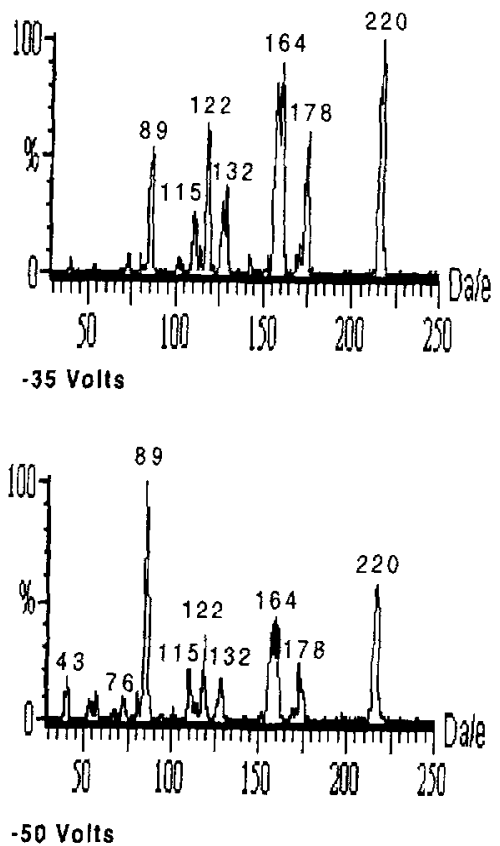

-50 Volts

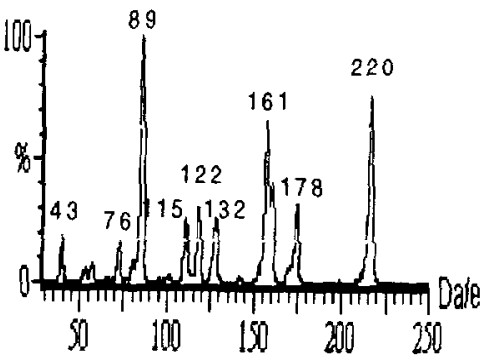

Figure 2. CID product spectra of compound I at collision cell potentials ranging from 0 to $50 \mathrm{~V}$.

mentation pathway of I at lower collision energies involves bond cleavage between the sulfur and the acrolein moiety, yielding protonated $\mathrm{N}$-acetylcysteine $(\mathrm{m} / \mathrm{z}$ 164) via retro-Michael reaction (Figure 3$)$. At higher collision energies, more products were generated including acetyl $(m / z 43)$ and $m / z 178$ (loss of ketene) analogous to the behavior of unmodified $N$ acetylcysteine. Fragmentation between the sulfur and the cysteine skeleton yields the protonated fragment $\mathrm{SR}_{x}(m / z 89)$ which is the most abundant product at collision cell potentials greater than $30 \mathrm{~V}$. Other fragments formed under more energetic conditions are protonated cysteine $(m / z$ 122) and $m / z 161$ (loss of acetamide). Energy resolved dissociation curves for protonated I (Figure 4a) illustrate the ease of formation of the retro-Michael product which dominates the product ion spectrum at low collision potentials $\left(E_{\text {lab }}<20\right.$ $\mathrm{eV})$.

Reduction of the aldehyde to an alcohol, yielding II, leads to marked changes in fragmentation dynamics (Figure $4 \mathrm{~b}$ ). In contrast to I, dissociation of protonated II yields no single dominant peak at any collision cell potential. The most abundant product at the lowest potential again arises via cleavage of a sulfur-carbon bond, but in the case of II this pathway involves loss of $\mathrm{R}_{x} \mathrm{SH}$ and formation of protonated $\mathrm{N}$-acetyldehydroalanine $(m / z 130)$ instead of loss of $\boldsymbol{R}_{x}$ which was not observed. CID spectra obtained at the three lowest potentials show two additional fragments in similar yields: loss of acetamide $(\mathrm{m} / \mathrm{z} 163)$ and loss of ketene $(\mathrm{m} / \mathrm{z} 180)$. This indicates that under these conditions II fragments via multiple pathways involve similar activation barriers, but the activation energies of these reactions are greater than for retro-Michael fragmentation of $\mathbf{I}$. At higher collision potentials, fragmentation of II yields $\mathrm{SR}_{x}(m / z$ 91). Appearance of these fragments indicate that sulfur is an important cleavage point for I and II, but conversion of the aldehyde to the alcohol resulted in a significant increase in the activation energy leading to loss of $R_{x}$.

The fragmentation behavior of oxime derivative III is similar to I (Figure 4c). At low collision cell voltages, the predominant fragmentation pathway yields the retro-Michael product, protonated $\mathrm{N}$-acetylcysteine at 


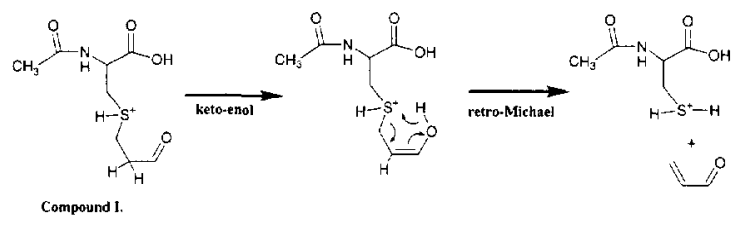

Figure 3. Proposed mechanism for retro-Michael fragmentation of compound $\mathbf{I}$.

$m / z 164$. Similarities in fragmentation between I and III point to a key role played by the $s p^{2}$ hybridization of the aldehyde or oxime groups in stabilizing the retroMichael transition state.

\section{Glutathione Conjugates}

Energy resolved product ion spectra of glutathione were obtained to establish the effect of the modifying group on fragmentation of the peptide backbone (data not shown). These spectra were obtained under the same collisional activation conditions used for all glutathione adducts in this study, and several key fragments are listed in Table 1. At all but the highest
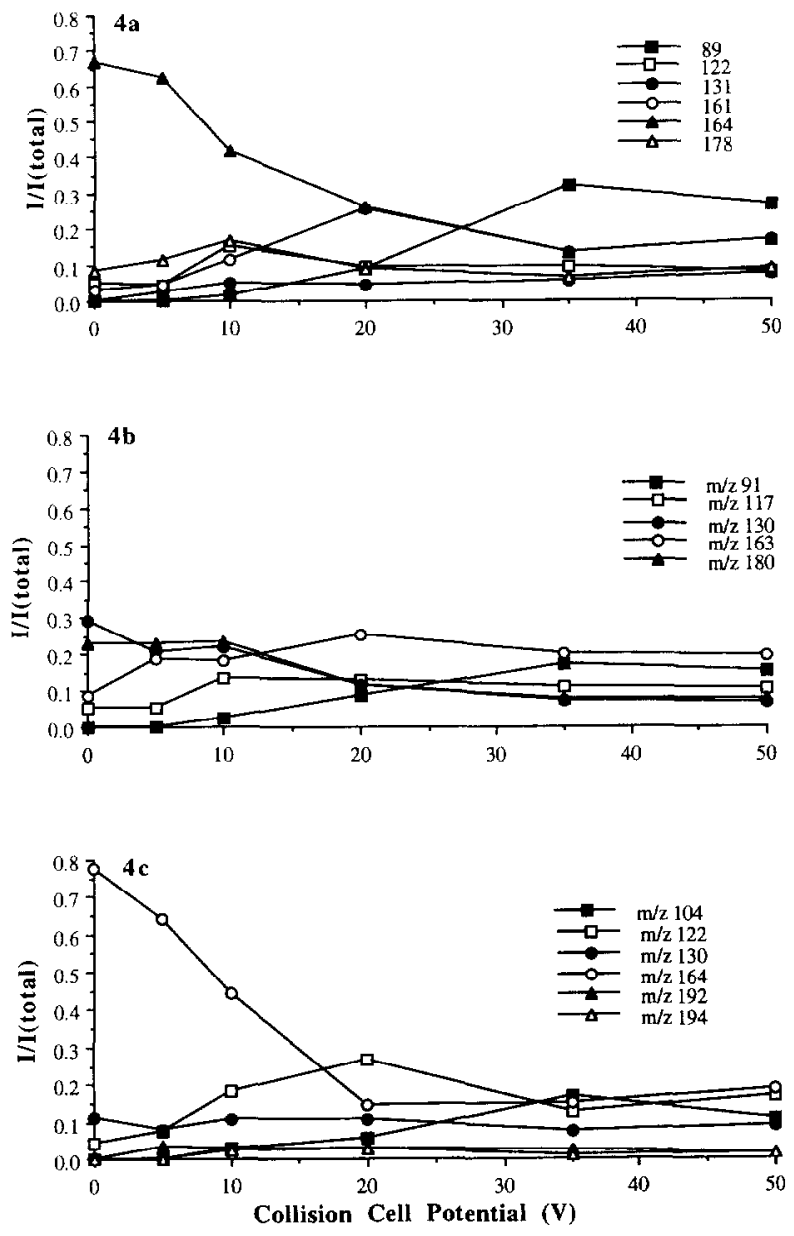

Figure 4. Energy resolved dissociation curves of selected ions of $N$-aretylcysteine analogs: (a) Compound I; (b) Compound II; (c) Compound III. collision cell potential, the predominant fragment observed is $y_{2}$, corresponding to loss of the $\gamma$-glutamyl group at $m / z 179$. This fragmentation route has been well documented in earlier studies $[3,4,13,15,17,20]$ and several investigations have taken advantage of this fragmentation by developing scans for neutral losses of 129 Da which improve specificity for detection of glt1tathione conjugates. $[3-8,13,17]$

At high collision cell voltages $(50 \mathrm{~V})$, the most abundant fragment results from cleavage at the cysteinyl-glycyl amide linkage to yield $y_{1}$, protonated glycine at $m / z$ 76. Other prominent fragments are: $b_{1}$, the glutamyl acylium ion $(m / z 130) ; \mathrm{a}_{1}-\mathrm{H}_{2} \mathrm{O}(m / z 84) ; z_{2}$, the Cys-Gly fragment minus the amino group of the cysteine ( $m / z 162)$; and $b_{2}$, the $\gamma$-Glu-Cys fragment $(m / z 233)$. At high collision cell potentials, the entire complement of $b$ and $y$ ions is observed suggesting sufficient proton mobility to facilitate fragmentation along the peptide backbone.

Under all collision conditions, the protonated glutathione adduct (IV) did not yield a detectable $y_{2}$ fragment, but instead gave a dominant $y_{2}-\mathrm{H}_{2} \mathrm{O}$ fragment $(m / z$ 217, Figure 5) at lower collision energies. The transient formation of $y_{2}$ cannot be ruled out, but was not observed at any cell potential or at lower collision gas pressures.

Because the $y_{2}$ fragment is not observed, a scan for neutral loss of 129 Da may not be effective in screening for acrolein thioether conjugates of glutathione in complex matrices. Other intramolecular Schiff base product ions formed from product ion $\mathbf{g}$ have been reported by Haroldsen et al., [13] and were observed in these experiments as well.

At higher collision cell voltages the $b_{1}$ fragment of IV is abundant, suggesting protonation occurs near the $\gamma$-glutamyl-cysteinyl amide linkage, but proton transfer does not lead to formation of $y_{2}$ fragments. Such reactions have been reported in fragmentation of glutathione and other glutathione thioether conjugates. [3, 4, $13,17,20]$ With the exception of the $y_{2}$ product, a full complement of $b$ and $y$ fragments is observed at a collision potential of $50 \mathrm{~V}$.

As discussed earlier, I retro-Michael elimination of acrolein predominates at low collision cell voltages. This fragmentation process is not observed in IV, and only one fragment, $\mathrm{SR}_{x}$ at $m / z 89$, can be attributed to cysteinyl-C-S bond cleavage. The $\mathrm{SR}_{x}$ fragment only appears at higher collision cell voltages.

Energy resolved dissociation curves for IV are shown in Figure 6a. These plots highlight the predominant formation of $y_{2}-\mathrm{H}_{2} \mathrm{O}$. At low collision energies, all other fragmentation routes combined contribute less than ten percent of total product ions. At collision potentials of $20 \mathrm{~V}$ and higher, other fragmentation routes become energetically accessible, but the route that leads to formation of $y_{2}-\mathrm{H}_{2} \mathrm{O}$ remains the most favorable.

As anticipated based on the behavior of II, reduction of IV to S-(3-hydroxypropyl)glutathione (V) results in 


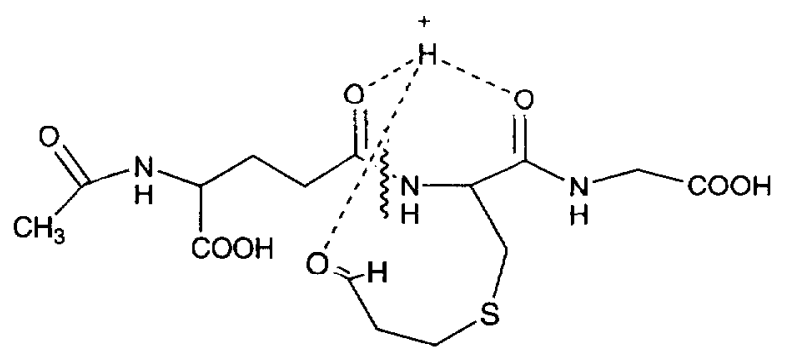
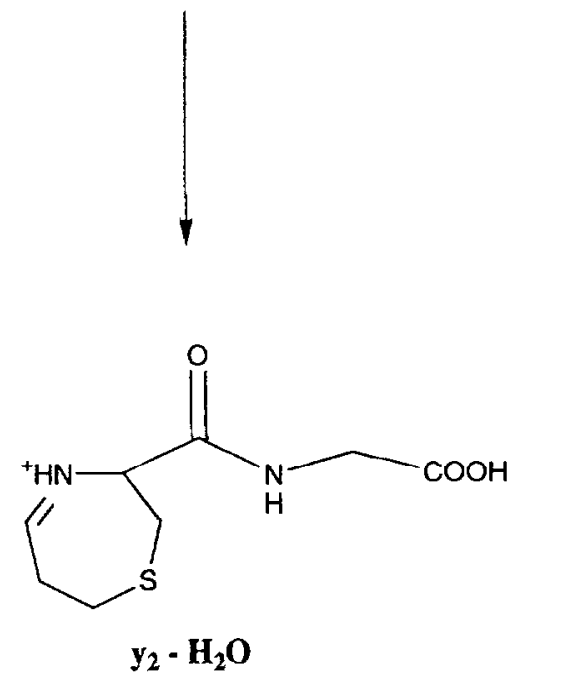

Figure 5. Proposed structure of $y_{2}-\mathrm{H}_{2} \mathrm{O}$ fragnient observed fur compounds IV, VI, and VIII.

product spectra with more fragments (data not shown). At a collision cell potential of zero volts, $y_{2}(\mathrm{~m} / z 237)$ and $z_{2}(m / z 220)$ fragments appear with low fractional abundances. At all lower collision cell potentials lested, the $z_{2}$ fragment dominates the spectra, but at higher collision potentials the internal fragment $\mathbf{h}(\mathrm{m} / z$ 118) and $b_{1}$ become most prevalent. The internal fragment $g$ $(m / z 134)$ is also present at higher collision cell voltages. An intramolecular Schiff base is not anticipated from decomposition of protonated $\mathbf{V}$ as it does in the $y_{2}-\mathrm{H}_{2} \mathrm{O}$ fragment from IV, because the aldehydic functionality of the acrolein conjugate is not present. As a result, no fragments indicating Schiff base formation are present.

Product spectra from protonated $\mathbf{V}$ show that fragments resulting from cleavage at the propanol-C-S bond are minor although cleavage of the $\mathrm{Cys}-\mathrm{C}-\mathrm{S}$ bond gives a more abundant fragment $\mathrm{SR}_{x}$ at $m / z$ 91. This fragmentation pathway was observed, however, for all thioether conjugates in this study at a collision potential of $50 \mathrm{~V}$.

Energy resolved product ion spectra of $\mathrm{V}$ show the entire complement of $b$ and $y$ ions and substantiate our earlier finding that reduction of the acrolein moiety produces more fragments at any given collision potential tested. Energy resolved dissociation curves of $\mathrm{V}$ (Figure 6b) are different from those observed for IV because there are two fragmentation routes at the low


Figure 6. Energy resolved dissociation curves for selected product ions derived from CID of protonated glutathione analog precursors: (a) Compound IV; (b) Compound V; (c) Compound VI.

collision potentials tested that produce minor amounts of $y_{2}$ and $z_{2}$ fragments. Despite their low activation energy barriers, these two fragmentation routes are not the most favored routes at higher collision potentials. In fact, the $y_{2}$ peak is diminished at collision cell potentials greater than $20 \mathrm{~V}$, perhaps due in part to subsequent fragmentation of the $y_{2}$ ion.

When IV is derivatized with hydroxylamine hydrochloride to give the acrolein-oxime product VI (data not shown), the fragment representing cleavage at the Cys$\mathrm{C}-\mathrm{S}$ bond $\left(\mathrm{SR}_{x}, m / z \mathrm{104}\right)$ dominates at higher collision cell potentials. This same fragment is prominent in the product ion spectrum of III taken at a collision voltage of $35 \mathrm{~V}$. A minor fragment, $\mathrm{R}_{x}$ at $m / z 72$ also is present at higher collision cell voltages, which is due to cleavage of acrolein-oxime-C-S bond. This fragment is analogous to the $\mathbf{R}_{x}$ peak at $m / z 56$ seen in the product spectra of IV.

One notable feature in the fragmentation of protonated VI is the appearance of an abundant product at $m / z$ 217. The low appearance energy of this peak (Figure $6 c$ ) is analogous to that seen for $m / z 217$ for IV, 
which would involve displacement of hydroxylamine in a manner analogous to displacement of water from IV. Formation of this product suggests both oximes and aldehydes are reactive toward neighboring amide nitrogens, and their presence may facilitate cleavage of these amide bonds. The energy resolved dissociation curves (Figure 6c) for VI are similar in appearance to those obtained for IV. Both have accessible fragmentation pathways with low activation energy barriers. These results combined with the fragmentation behavior of III suggest that derivatization of Michael thioether adducts of aldehydes or ketones to form oximes is unlikely to yield more useful fragmentation than can be obtained for the underivatized adduct.

Fragments at $m / z 84,130,162$, and 179 are observed in the product spectra of both IV and VI. Product spectra of $\mathbf{V}$ also include fragments at $m / z 84$ and 130. All of these fragments arise from the glutathione portion of the molecule and therefore do not provide information regarding the nature of the modifying group.

\section{$\mathrm{N}$-Acetylglutathione Conjugates}

Energy resolved product ion spectra of $\mathrm{N}$-acetylglutathione (not shown) exhibit marked differences from glutathione. At the lowest collision cell potentials tested, several fragmentation pathways have comparable activation energies resulting in multiple product ions. These spectra suggest that the precursor ion is heterogeneous with respect to site of protonation, because several peaks are present including the entire complement of $b$ and $y$ ions.

Energy resolved dissociation curves for compound VII are shown in Figure 7a. A notable feature is the abundance of fragments at lower collision potentials. Acylation at the $N$-terminus eliminates the basic amino group, thus protonation becomes more delocalized than for glutathione.

As expected, the fragmentation behavior of $\mathrm{N}$-acetylS-(3-oxopropyl)-glutathione (VIII) shares many characteristics observed for VII as well as IV. As was the case in product spectra of IV, the $\mathrm{N}$-acetylated analog VIII does not yield $y_{2}$, but $y_{2}-\mathrm{H}_{2} \mathrm{O}(m / z 217)$, again with a low activation energy. Based on the ease of formation of $y_{2}-\mathrm{H}_{2} \mathrm{O}$, it is proposed that acrolein may serve as a volatile derivatizing agent for cysteine residues capable of inducing low activation energy fragmentation on the $\mathrm{N}$-terminal side of cysteine groups in CID experiments.

Retro-Michael fragmentation of VII would yield a fragment with $m / z$ 350. A small peak at this mass was observed, but only at the highest collision potential tested. These results indicate that even in the absence of a basic amino group, protonation at the thioether sulfur was not significant when multiple amide bonds were present.

Energy resolved dissociation curves for VIII are shown in Figure $7 \mathrm{~b}$. At a collision potential of $0 \mathrm{~V}$, VIII cleaves at the cysteinyl-glycyl amide bond to give
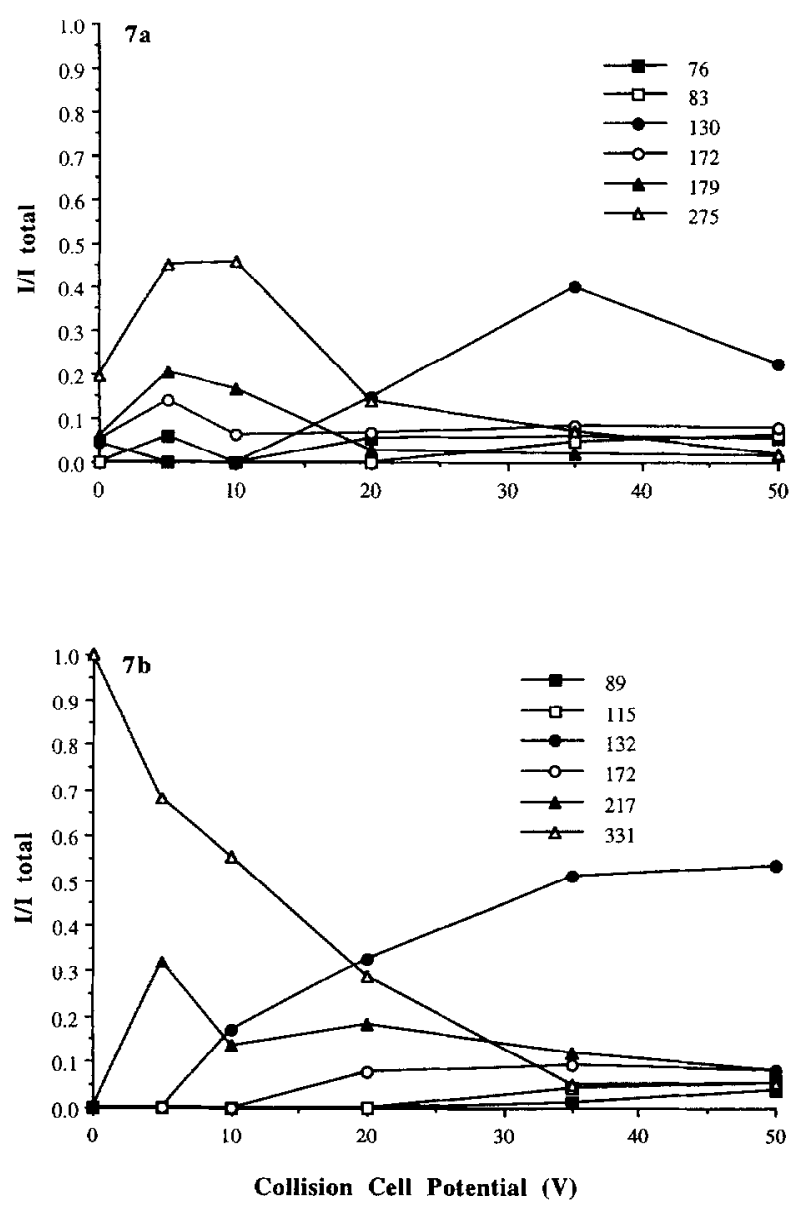

Figure 7. Energy resolved dissociation curves of selected product ions derived from CID of protonated $N$-acetylglutathione analogs: (a) Compound VII; (b) Compound VIII.

exclusively $b_{2}(m / z 331)$. At a collision potential of $5 \mathrm{~V}$, a second fragment representing $y_{2}-\mathrm{H}_{2} \mathrm{O}(\mathrm{m} / z$ 217) accounts for about $30 \%$ of products. At higher potentials the $\mathrm{g}$ fragment $(\mathrm{m} / z \mathrm{132})$ is most abundant, while the rest of the fragments share similar relative intensities.

In low energy CID experiments, most fragmentations are charge directed $[26,28,31,32,34]$. Chargeremote fragmentation usually involves high activation energies $[31,32,35,43-45]$. It is expected to play a minor role in our experiments, because center-of-mass collision energies exceeding $10 \mathrm{eV}$ are often required for charge-remote fragmentations to become dominant [43, 45]. Such reactions cannot be ruled out because centerof-mass collision energies in the experiments described herein range between $4-8 \mathrm{eV}$, and these experiments were conducted under multiple collision conditions.

If the fragmentation processes with the lowest activation energies are charge directed, the dominant retroMichael fragmentation for I and III suggests protonation occurs at the sulfur for these $N$-acetylcysteine derivatives. Furthermore, II fragments primarily at the sulfur at low collision potentials, only the fragmentation is loss of $\mathrm{SR}_{x}(m / z 130)$. While it is widely believed 
that the peptide backbone is an important site of protonation $[29,30,32,34,35,46]$, the differences in behavior of the compounds investigated herein can be attributed to several factors. In aqueous solution, protonated peptide $N$-terminal amino groups are stabilized by solvation $[29,46]$. In the gas phase, charge delocalization can be accomplished by internal solvation of the charge by amide groups $[29,34,47]$. The proton affinity of formamide is $198.8 \mathrm{kcal} / \mathrm{mol}$ [47], which approximates the intrinsic proton affinity of a single amide group. Additional amide groups, such as those present in the glutathione conjugates, enhance the proton affinity, as illustrated by the proton affinities of dipeptides Gly-Gly and Ala-Ala, which are 208 and $210 \mathrm{kcal} / \mathrm{mol}$, respectively [48]. Proton affinities increase with each additional amide bond with a maximum effect reached at three amide linkages [48]. In addition, coordination of a proton with up to three proton acceptors is possible (albeit with diminishing bond strength per coordinate) $[46,47]$. Since the $N$-acetylcysteine derivatives I, II, and III have only one amide group, the proton is less likely to be localized at an amide group, and the thioether group is more able to serve as a site of protonation. Proton affinities of formamide [47], propionaldehyde [49], and diethylsulfide [49] are 198.8, 193.6, and 205.6 $\mathrm{kcal} / \mathrm{mol}$, respectively. Proton affinity of the sulfur in acrolein conjugates may be enhanced by coordination of the proton with the acrolein aldehyde and the thioether sulfur, with a bridging proton forming a six-membered ring. Differences in fragmentation behavior between $N$-acetylcysteine derivatives and glutathione derivatives can be explained by the ranking of basicities (single amide $<$ thioether $<$ multiple amides) and charge-directed fragmentation.

\section{Conclusions}

Retro-Michael fragmentation is the lowest activation energy fragmentation pathway for protonated acrolein conjugates of $\mathrm{N}$-acetylcysteine, and the retro-Michael product dominates low energy CID spectra of these compounds even under multiple collision conditions. The low barriers to these reactions are attributed to protonation at thioether sulfur and stabilization of the retro-Michael transition state owing to the electronic configuration of these molecules. Similar behavior can be expected for other Michael addition conjugates of $N$-acetylcysteine.

In contrast, retro-Michael fragmentation was not a competitive reaction for glutathione and $N$-acetylglutathione conjugates of acrolein. For these compounds, the proton is more effectively sequestered by the amide groups. Spectra of glutathione and $N$-acetylglutathione conjugates show a complement of $b$ and $y$ type ions to illustrate this point. Retro-Michael fragmentation of the $N$-acetylglutathione adduct VIII was minimal, suggesting that the peptide backbone efficiently sequesters the proton and diminish protonation of thioether sulfur, even in the absence of a basic $N$-terminal amino group.
Reduction of the aldehydic carbonyl of thioether conjugates formed from $\alpha, \beta$-unsaturated aldehydes or ketones is an effective method of chemical modification that prevents retro-Michael fragmentation in $\mathrm{N}$-acetylcysteine Michael adducts. Conversion of the aldehyde group to an oxime had only minor effects upon fragmentation.

Acrolein adducts of glutathione (IV) and $N$-acetylglutathione (VIII) did not give significant $y_{2}$ fragments under any conditions, but both yielded abundant $y_{2}$ $\mathrm{H}_{2} \mathrm{O}$ fragments via a low activation energy pathway. Strategies that rely on specific neutral losses based upon elimination of the glutamyl group should be conducted with this in mind. Such specific cleavages on the $N$ terminal side of acrolein adducts of cysteine residues might be exploited to localize cysteine sulfhydryls in peptides.

\section{Acknowledgments}

The authors acknowledge the technical assistance of Wanda Smith of the UC Davis NMR Facility for generating NMR spectra. The NMR spectrometer was purchased with funds from NSF grant no. DIR90-16484. This work has been supported by NIEHS Superfund Basic Research Program (grant no. 2P42 ES-04699) and the NIEHS Center for Environmental Health Science at UC Davis (grant no 1P30 ES-05707). This work was presented in part at the 43rd Annual ASMS Conference on Mass Spectrometry and Allied Topics, held in Atlanta, GA, May 21-25, 1995.

\section{References}

1. van Welie, R. T. H.; van Dijck, R. G. J. M.; Vermeulen, N. P. E.; van Sittert, N. J. Crit. Rev. Tuxicol. 1992, 22, 271-306.

2. Nelson, E. Crit. Rev. Toxicol. 1992, 22, 371-389.

3. Pearson, P. G.; Threadgill, M. D.; Howald, W. N.; Baillie, T. A. Biomed. Environ. Mass Spectrom. 1988, 16, 51-56.

4. Straub, K. M. In Mass Spectrometry in Biomedical Research; Gaskell, S. J., Ed.; Wiley: New York, 1986; pp 115-134.

5. Davis, M. R.; Baillie, T. A. J. Mass Spectrom. 1995, 30, 57-68.

6. Davis, M. R.; Kassahun, K.; Jocheim, C. M.; Brandt, K. M.; Baillie, T. A. Chem. Res. Toxicol. 1993, 6, 376-383.

7. Kassahun, K.; Hu, P.; Grillo, M. P.; Davis, M. R.; Jin, L.; Baillie, T. A. Chem. Biol. Interact. 1994, 90, 253-275.

8. Jin, L.; Davis, M. R.; Kharasch, E. D.; Doss, G. A.; Baillie, T. A Chem. Res. Toxicol. 1996, 9, 555-561.

9. Bruenner, B. A.; Jones, A. D.; German, J. B. Chem. Res. Toxicol. $1995,8,552-559$.

10. Esterbauer, H.; Zollner, H.; Scholz, N. Z. Naturforsch. 1975, 30c, 466-473.

11. Bolgar, M. S.; Gaskell, S. J. Anal. Chem. 1996, 68, 2325-2330.

12. Kaur, S.; Hall, S. C.; Burlingame, A. L. Prog. Clin. Biol. Res. $1991,372,107-117$.

13. Haroldsen, P. E.; Reilly, M. H.; Hughes, H.; Gaskell, S.J. Biomed. Environ. Mass Spectrom. 1988, 15, 615-621.

14. Fearson, P. G.; Slatter, J. G.; Rashed, M. S.; Han, D.-H.; Grillo, M. P.; Baillie, T. A. Biochem. Biophys. Res. Commun. 1990, 166, 245-250.

15. Deterding, L. J.; Srinivas, P.; Mahmood, N. A.; Burka, L. T.; Tomer, K. B. Anal. Biochem. 1989, 183, 94-107.

16. Ackerman, B. L.; Watson, J. T.; Newton, J. F.; Hook, J. B.; Braselton, W. E., Jr. Biomed. Mass Spectrom. 1984, 11, 502-511.

17. Ballard, K.; Raftery, M. J.; Jaeschke, H.; Gaskell, S. I. I. Am. Soc. Mass Spectrom. 1991, 2, 55-68. 
18. Baillie, T. A.; Pearson, P. G.; Rashed, M. S.; Slatter, J. G.; Howald, W. N. In Biological Mass Spectrometry; Burlingame, A. L.; McCloskey, J. A., Eds.; Elsevier: Amsterdam, 1990; pp 567-578.

19. Pearson, P. G.; Howald, W. N.; Nelson, S. D. Anal. Chem. 1990, $62,1827-1836$.

20. Murphy, C. M.; Fenselau, C.; Gutierrez, P. L. J. Am. Soc. Mass Spectrom. 1992, 3, 815-822.

21. Lay, J. O., Jr.; Potter, D. W.; Hinson, J. A. Biomed. Environ. Mass Spectrom. 1987, 14, 517-521.

22. Heeremans, C. E. M.; te Koppele, J. M.; Niessen, W. M. A.; van der Greef, J.; Brussee, J.; La Vos, G. F.; ten Neover de Brauw, M. C. Biomed. Environ. Mass Spectrom. 1988, 17, 181-186.

23. McLuckey, S.; Glish, G. L.; Cooks, R. G. Int. J. Mass Spectrom. Ion Phys. 1981, 39, 219-230.

24. Fetterolf, D. D.; Yost, R. A. Int. J. Mass Spectrom. Ion Phys. 1982, 44, 37-50.

25. Nacson, S.; Harrison, A. G. Int. J. Mass Spectrom. Ion Proc. 1985, $63,325-337$

26. McLuckey, S. A.; Cooks, R. G. In Tandem Mass Spectrometry; McLafferty, F. W., Ed.; Wiley: New York, 1983; pp 303-320.

27. Dawson, P. H.; Douglas, D. J. In Tandem Mass Spectrometry; McLafferty, F. W., Ed.; Wiley: New York, 1983; pp 125-148.

28. Hayes, R. N.; Gross, M. L.; McCloskey, J. A., Eds.; In Methods in Enzymology, Vol. 193; Academic: New York, 1990; pp 237-263.

29. Hunt, D. F; Yates, J. R., III; Shabanowitz, J.; Winston, S.; Hauer, C. R. Proc. Natl. Acad. Sci. USA 1986, 83, 6233-6237.

30. Tang, X.-J.; Thibault, P.; Boyd, R. K. Anal. Chem. 1993, 65 , $2824-2834$.

31. Burlet, O.; Orkiszewski, R. S.; Ballard, K. D.; Gaskell, S. J. Rapid Commun. Mass Spectrom. 1992, 6, 658-662.
32. Burlet, O.; Yang, C.-Y.; Gaskell, S. J. J. Am. Soc. Mass Spectrom. 1992, 3, 337-344.

33. Poulter, L.; Taylor, L. C. E. Int. J. Mass Spectrom. Ion Proc. 1989, 91, 183-197.

34. Tang, X.-J.; Boyd, R. K. Rapid Commun. Mass Spectrom. 1992, 6, $651-657$

35. Cox, K. A.; Gaskell, S. J.; Morris, M.; Whiting, A. J. Am. Soc. Mass Spectrom. 1996, 7, 522-531.

36. Cohen, S. M.; Garland, E. M.; St. John, M.; Okamura, T.; Smith R. A. Cancer Res. 1992, 52, 3577-3581.

37. Ramu, K.; Fraiser, L. H.; Mamiya, B.; Ahmed, T.; Kehrer, J. P. Chem. Res. Toxicol. 1995, 8, 515-524.

38. Patel, J. M.; Block, E. K. 'Toxicol. Appl. Pharmacol. 1993, 122, 46-53.

39. Mahut, B.; Delacourt, C.; de Blik, J.; Mani, T. M.; Scheinmann, P. Chest 1993, 104, 1286-1287.

40. Hashmi, M.; Vamvakas, S.; Anders, M. W. Chem. Res. Toxicol. 1992, 5, 360-365.

41. Roepstorff, P.; Fohlman, J. Biomed. Environ. Mass Spectrom. 1984, 11, 601

42. Biemann, K. Biomed. Environ. Mass Spectrom. 1988, 16, 99-111.

43. Adams, J. Mass Spectrom. Rev. 1990, 9, 141-186.

44. Alexander, A. J.; Thilbault, P.; Boyd, R. K. Rapid Commun. Mass Spectrom. 1989, 3, 30.

45. Feistner, G. J.; Hsieh, L. L. J. Am. Soc. Mass Spectrom. 1995, 6, 836-846.

46. Yeh, R. W.; Grimley, J. M.; Bursey, M. M. Biol. Mass Spectrom. 1991, 20, 443-450.

47. Meot-Ner (Mautner), M. J. Am. Chem. Soc. 1984, 14, 278-283.

48. Wu, J.; Lebrilla, C. B. J. Am. Soc. Mass Spectrom. 1995, 6, 91-101.

49. Harrison, A. G. Chemical Ionization Mass Spectrometry, 2nd ed.; CRC: Boca Raton, 1993. 